\title{
Going Where the Money Is: Strategies for Taxing Economic Elites in Unequal Democracies
}

\author{
TASHA FAIRFIELD * \\ London School of Economics, UK
}

\begin{abstract}
Summary. - How can policymakers circumvent obstacles to taxing economic elites? This question is critical for developing countries, especially in Latin America where strengthening tax capacity depends significantly on tapping under-taxed, highly-concentrated income and profits. Drawing on diverse literatures and extensive fieldwork, the paper identifies six strategies that facilitate enactment of modest tax increases by mobilizing popular support and/or tempering elite antagonism. Case studies from Chile, Argentina, and Bolivia illustrate the effect of these strategies on the fate of tax reform initiatives. The analysis builds theory on tax politics and yields implications for research on reform coalitions and gradual institutional change.

(c) 2013 Elsevier Ltd. All rights reserved.
\end{abstract}

Key words - comparative politics, Latin America, economic elites, inequality, tax reform, politics of policymaking

\section{INTRODUCTION}

Contentious debates and political battles over tax policy made headlines around the world in the context of the global financial crisis, precipitous budget deficits in the United States, and the Euro-zone debt crisis. While these events focused attention on advanced northern democracies, taxation has long been a pressing and politically charged issue in the developing world. The stakes are high: weak tax capacity undermines fiscal discipline and economic stability, and inadequate revenue restricts investment in human capital, poverty alleviation, and provision of basic social services.

Revenue-raising tax reform is particularly challenging in developing countries characterized by extreme inequality and overreliance on consumption taxes, as is the case in much of Latin America. Income in this region is heavily concentrated, not just in the top $10 \%$ of households, but in the very top percentiles (Alvaredo, 2010). Whereas many Latin American countries collect substantial revenue from consumption taxes, income is a major, under-tapped tax base (Gomez-Sabaini, 2006). Revenue from direct taxes on income and profits tends to be low not only in absolute terms, but also compared to countries with similar development levels (Perry, López, Maloney, \& Servén, 2006). To a significant extent, raising more revenue therefore requires directly taxing economic elites. Yet such initiatives impose predictable and immediate losses on precisely those taxpayers who are often best positioned to influence policy decisions.

How can policy entrepreneurs circumvent obstacles to taxing economic elites? And how much scope for reform can they create? These questions are of growing interest to the international development community and policy practitioners, ${ }^{1}$ but they have received little systematic analysis in the emerging literature on tax reform in developing countries. Tax-policy literature has not adequately analyzed the critical political dimensions of tax reform. Meanwhile, political scientists have primarily examined value-added tax (VAT) reforms implemented during structural adjustment in the 1980s and 1990s, which posed distinct political challenges (Eaton, 2002; Mahon, 2004). ${ }^{2}$ Comparative historical analysis on state-building identifies factors that contributed to direct tax capacity, including wars (Tilly, 1975 and others), exclusionary racial cleavages
(Lieberman, 2003), colonial legacies (Mkandawire, 2010) or other path-dependent processes (Kurtz, 2009), and patterns of contentious politics (Slater, 2010). Yet in many developing countries these factors were not present or did not produce significant direct tax capacity, and they are unlikely candidates for effecting change in the contemporary period. ${ }^{3}$ Literature on fiscal bargaining argues that states can extract more revenue when taxpayers are granted representation or participation in governance or when spending benefits them directly (Bates \& Lien, 1985; Brautigam, Fjeldstad, \& Moore, 2008; Levi, 1988; Timmons, 2005). But when taxable resources are extremely concentrated and governments need revenue to provide benefits for the broader populace, offering elites greater political participation or material benefits in exchange for their tax-dollars may be counterproductive.

Drawing on diverse literatures and extensive original field research, I identify and analyze six strategies for taxing economic elites and argue that they can have an important causal effect on the fate of reform initiatives. The strategies act through one or both of two mechanisms. First, they may mobilize public support, which puts electoral pressure on politicians who might otherwise defend the interests of economic elites. Second, they may temper antagonism on the part of those economic elites who will bear the tax burden, making them more likely to accept reform. When economic elites are powerful, these strategies are unlikely to make substantial tax increases possible. Nevertheless, they can make the difference between no additional resources and much needed if modest supplemental revenue, and the incremental reforms they facilitate may accumulate into significant change over time.

\footnotetext{
${ }^{*}$ Fieldwork was supported by a Social Science Research Council dissertation fellowship and a Fulbright-Hays doctoral dissertation research fellowship. I thank Taylor Boas, Andrew Charman, David Collier, Kent Eaton, Peter Evans, Gustavo Flores-Macías, James McGuire, Jonathan Hopkin, Diana Kapiszewski, Marcus Kurtz, and Wilson Prichard for insightful comments and suggestions at various stages of this project. I also thank LSE's political economy working group, DIE's Mobilizing Domestic Revenue workshop, four anonymous reviewers, and the World Development editorial staff. Final revision accepted: February 16, 2013.
} 
My focus on direct taxation runs against policy views that prevailed in the 1980s and 1990s, which assumed that taxing economic elites was administratively impossible and inherently inefficient. However, a new policy consensus is emerging in favor of strengthening direct taxation, particularly for Latin America (Barreix, Roca, \& Villela, 2006; Gomez-Sabaini, Jiménez, \& Rossignolo, 2012; IMF, 2011: 40; Perry et al., 2006), ${ }^{4}$ given two key considerations. First, tax administration has improved dramatically in many countries that underwent structural adjustment, and while taxing economic elites remains administratively challenging, specialized large-taxpayer auditing units, withholding regimes, tax agency access to bank information, third party reporting, and other innovations that reduce opportunities for evasion have made the task more feasible. Further, eliminating income-tax loopholes and broadening direct tax bases simultaneously raises revenue, curtails avoidance, and simplifies tax administration. Second, current research shows that the efficiency costs of direct taxation are not necessarily prohibitive. In fact, progressive direct taxation can be optimal for raising revenue when the income distribution is heavily skewed (Piketty, Saez, \& Stantcheva, 2011; Saez, 2001). ${ }^{5}$ While increasing direct taxation of economic elites is most relevant in highly unequal countries where broad-based VATs have already been implemented, many of the strategies I discuss are also relevant where tax increases affecting nonelite taxpayers are advisable.

Section 2 of the paper begins by outlining my theoretical framework for assessing obstacles to direct tax reform associated with economic elites' political power and investment power. These two types of power correspond to distinct means of influence. I then explicate strategies for circumventing obstacles to reform. Many of these strategies are noted or have analogs in literature on welfare-state development and retrenchment in advanced industrial democracies, market-reform coalitions in developing and postcommunist countries, redistributive experiments in Latin America, and fiscal bargaining. However, they have not been analyzed systematically and comprehensively with respect to the goal of taxing economic elites. My contribution lies in identifying and drawing these strategies together, conceptualizing, classifying and analyzing them with respect to an underlying theory of how economic elites exert influence, assessing the strategies' relative advantages and limitations, and identifying conditions under which they may be more or less successful. 6

Section 3 illustrates how these strategies can affect the fate of tax reform proposals by analyzing cases from Chile, Argentina, and Bolivia in which economic elites had strong political and/or investment power. I argue that astute reform strategies helped governments legislate incremental income tax increases in Chile, whereas strategic errors ensured the failure of an income tax reform in Bolivia. In Argentina, a sophisticated policy-design strategy helped the government redress a costly income-tax loophole; however, an intrinsic drawback of the strategy employed led to the reform's repeal a year later. The conclusion extracts comparative lessons regarding the importance of policy design and framing, as well as implications for research on economic reform and gradual institutional change.

\section{THEORETICAL FRAMEWORK}

Investment power and political power, known respectively as structural power and instrumental power in business politics literature, 7 correspond to two distinct means through which economic elites can exert influence. Investment power creates economic obstacles to reform; political power creates political obstacles. Investment power arises from concerns that a reform will provoke reduced investment or capital flight, because of the market incentives the reform creates for profitmaximizing firms and individuals. Reduced investment may in turn hurt growth and employment, thereby jeopardizing policymakers' developmental goals and/or leading to punishment at the polls. If policymakers anticipate reduced investment, they may therefore refrain from initiating the reform. The defining feature of investment power is that it requires no organization or political action on the part of economic elites; instead, market signals induce coordinated reactions in the economic arena.

In contrast, political power involves deliberate actions, like lobbying and various forms of collective action. Favorable relationships with policymakers are sources of political power that make such actions more likely to succeed. These relationships may include informal ties to policymakers; recruitment into government, whereby economic elites receive executivebranch appointments; and partisan linkages, whereby economic elites are a party's core constituency - the sector most important to the party's political agenda (Gibson, 1996). These relationships enhance access to policymakers and may create bias in favor of economic elites. Other sources of political power that help economic elites pursue their interests more effectively include organization, technical expertise, media access, and of course money. For example, strong encompassing organizations help business groups unify their demands and coordinate lobbying, which improves their bargaining position.

When economic elites have strong power of either type, increasing progressive direct taxes will be difficult; the more sources of power they possess, the greater the obstacles to reform. However, astute governments can legislate modest tax increases even when economic elites are powerful using strategies that temper elite antagonism and/or mobilize public support. Most of these strategies are intimately related to reform design. At the same time, many require concerted framing efforts. While the relative importance of "crafted talk" versus policy design has been debated (Hacker \& Pierson, 2005; Jacobs \& Shapiro, 2000), I find that both components can be mutually reinforcing and critical for taxing economic elites.

I classify six reform strategies according to their fiscal policy domain. Tax-side strategies exploit characteristics of the chosen tax instrument(s). These strategies include attenuating impact, obfuscating incidence, and legitimating appeals. In contrast, benefit-side strategies deflect debate away from taxation by focusing attention on benefits associated with the tax increase, the reform package in which it is nested, or a broader policy agenda. Benefit-side strategies include compensation, emphasizing stabilization, and linking to popular benefits.

The typology in Figure 1 locates the reform strategies according to the primary mechanism through which they act and their fiscal policy domain. Strategies that temper antagonism can make economic elites less inclined to use their political power to resist reform. Tempering antagonism can also circumvent investment power by reducing the likelihood that economic elites will disinvest. Strategies that mobilize public support can counterbalance economic elites' political power by creating electoral incentives for politicians with whom economic elites enjoy favorable relationships to be less responsive to elite interests. In accord with Collier et al.'s (2012) research on typologies, Figure 1 helps organize theory and concepts, synthesizes insights from disparate lines of research, and maps variation in the independent variable: reform strategies. 


\begin{tabular}{cccc}
\hline & \multicolumn{2}{c}{ Mechanism } \\
\cline { 3 - 4 } & Tax-Side & $\begin{array}{c}\text { Tempering Elite Antagonism } \\
\text { Circumvents elites' political } \\
\text { and/or investment power }\end{array}$ & $\begin{array}{c}\text { Mobilizing Public Support } \\
\text { Counterbalances elites' } \\
\text { political power }\end{array}$ \\
\cline { 3 - 4 } $\begin{array}{c}\text { Fiscal } \\
\text { Policy } \\
\text { Domain }\end{array}$ & $\begin{array}{c}\text { Attenuating Impact } \\
\text { Obfuscating Incidence } \\
\text { Legitimating Appeals } \\
\text { (Horizontal Equity) }\end{array}$ & $\begin{array}{c}\text { Legitimating Appeals } \\
\text { (Vertical Equity) }\end{array}$ \\
\cline { 3 - 4 } & Benefit-Side & Compensation & Linking to Popular Benefits \\
& Emphasizing Stabilization & \\
\hline
\end{tabular}

Figure 1. Reform strategies.

Each strategy has limitations and drawbacks. Tempering elite antagonism may entail marginal revenue gains and/or fiscal cost; on the other hand, public opinion may have limited influence on legislators' policy positions. Although some strategies are complementary, others are incompatible. And several strategies are applicable only in particular circumstances. Nevertheless, each strategy has facilitated reforms that otherwise may not have been possible.

\section{(a) Tax-side strategies}

The three tax-side strategies act through different means. Attenuating impact and obfuscating incidence temper antagonism. Legitimating appeals, which can be based on vertical equity or horizontal equity, mobilize public support; horizontal equity appeals can also temper elite antagonism.

\section{(i) Attenuating impact}

This strategy draws on the common-sense observation that economic elites will be less inclined to actively oppose, or reduce investment in response to a tax increase, the smaller its impact on their profits or pocket-books. Various temporal techniques attenuate impact. A tax increase can be phased-in gradually over time. Phase-ins give firms a transition period to finish projects initiated under the previous tax regime and adjust to higher taxation. Reformers can enact incremental tax increases spread out over time rather than attempting to pass a single more significant reform. A tax increase can also be legislated to hold effect for a delimited time period. These attenuation techniques can be viewed as "foot in the door" strategies (Ascher, 1984: 131). For example, renewing temporary tax increases at a later date may incur less political resistance than passing the initial reform, to the extent that taxpayers become accustomed to the increase and/or the government can demonstrate that it has not harmed investment.

However, these techniques have the obvious drawback of fiscal cost. If a government needs significant revenue in the short-term, phase-ins and incremental increases may be undesirable. Further, repeated recourse to temporary increases may undermine this technique, as taxpayers learn that temporary legislation will either be renewed or replaced with additional temporary tax increases.

\section{(ii) Obfuscating incidence}

Obfuscating tax incidence ${ }^{8}$ reduces taxpayers' awareness of paying the burden. Economic elites will not react against a tax increase by using their political power or by disinvesting if they are not conscious of how it will affect them. Obfuscation entails selecting taxes with low visibility (Steinmo, 1993; Wilensky, 2002). Direct taxes on income or assets tend to be highly visible. When individuals file income tax returns, they are acutely aware of the tax burden imposed upon them. In contrast, employers' social security contributions have low visibility (Steinmo, 1993: 19). Employers pass on the cost of these taxes to employees through lower wages. But because these taxes are collected from employers, wage earners generally are unaware that they bear the burden. ${ }^{9}$ This example illustrates a technique for reducing tax visibility: exploiting the phenomenon of burden-shifting, which stems from "the difference between the de jure and de facto incidence of taxes," (Pierson, 1994: 21).

Obfuscating strategies have several limitations and drawbacks. First, reducing visibility can introduce actual uncertainty regarding incidence. It may not be clear whether the economic assumptions required to successfully exploit burden-shifting actually hold, in which case, taxpayers other than those intended may be affected. Further, if a reform's incidence becomes too uncertain, business actors may strongly resist because of the difficulties it creates for anticipating costs and planning future investments. As Ascher (1989: 464) observes: "The frequently negative 'reflex' reaction to a new tax reform initiative on the part of many groups is typically due not just to expected losses but also to the risk of incurring costs that cannot be anticipated."

Second, reducing the visibility of taxes affecting economic elites is rarely feasible. Elites, unlike average citizens, have the motivation and the resources to ascertain exactly how tax reforms affect their pocket books, with ample recourse to tax accountants. As Hacker and Pierson (2005: 37) point out: "F. Scott Fitzgerald was right: The very rich are different-not just in their preferences regarding tax policy but, crucially, in their level of knowledge with respect to various dimensions of this complex issue."

\section{(iii) Legitimating appeals}

Legitimating appeals draw on widely held norms, often fairness or equity. A tax increase congruent with such norms has inherent legitimacy. Legitimating appeals can mobilize public support and thereby pressure politicians who might otherwise defend elite interests to accept reform. Wilson (1980: 370) envisages these strategies in his discussion of policies that impose costs on small groups but confer broad benefits, for 
which success "requires the efforts of a skilled entrepreneur who can mobilize latent public sentiment... put the opponents of the plan publicly on the defensive... and associate the legislation with widely shared values."

Legitimating appeals are more likely to succeed when political competition is strong and issue salience is high, such that politicians have electoral incentives to cater to marginal voters (Murillo, 2009), and when major elections are approaching, so that citizens are more likely to remember politicians' policy positions when they cast their votes (Jacobs \& Shapiro, 2000). However, the nature of political competition and voter-party linkages conditions the effectiveness of legitimating appeals. Strong partisan identities, cross-cutting voter preferences, clientelism, and charismatic linkages may provide ample opportunities for politicians to win votes even if their policy positions deviate from median-voter preferences. ${ }^{10}$ For these reasons, strategies for cultivating public support tend to influence tax politics only at the margins when economic elites enjoy strong political power. Despite these caveats, legitimating appeals can help governments legislate reforms that might not otherwise be feasible.

Vertical equity. Vertical equity is the principle that taxpayers who earn more or own more assets should bear a larger share of the tax burden - that is, taxation should be progressive. Reforms that are not only progressive but also highly targeted at elites are especially well-suited for vertical equity appeals. Targeting refers to how exclusively a tax increase affects upper-income sectors as opposed to middle- or lower-income sectors. Increasing the top marginal income tax rate targets elites more than reducing minimum allowances for all income tax payers. Likewise, excise taxes on luxury goods are more elite-targeted than VAT increases, which affect consumers more broadly. While elite-targeted tax increases are inherently progressive, not all progressive tax increases are highly elite-targeted.

Vertical equity appeals will be more effective when tax increases narrowly target elites. Where income is extremely concentrated, even a reform that affects only the top income decile may include individuals who can be construed as "middle class"-usually professionals who are not manifestly "rich" according to cultural norms or international comparison. Economic elites and their political allies often frame tax increases as affecting the "middle class" to justify their opposition. Such assertions are harder to sustain the more elite-targeted the reform.

However, economic elites may be able to shape public opinion to their own ends by framing tax increases in terms of principles other than vertical equity, even in highly unequal societies where the vast majority would be unaffected by the tax increase. For example, Birney, Shapiro, and Graetz (2008) find that proponents of estate tax repeal in the United States successfully framed the tax as a "death tax," connoting moral inappropriateness, rather than a tax on extraordinary wealth.

Further, while vertical equity appeals can mobilize public support, they pose the potential drawback of provoking more intense elite opposition. Although targeting and visibility need not co-vary, elite-targeted taxes are often highly visible and may therefore exacerbate elite antagonism.

Horizontal equity. Horizontal equity implies that taxpayers of similar economic means should bear similar tax burdens, regardless of their income sources. Examples of reforms that improve horizontal equity include eliminating sector-specific corporate tax benefits and broadening personal income tax bases to include nonwage income sources. Anti-evasion reforms also improve horizontal equity by ensuring that all taxpayers pay their due burden.

Because many reforms that enhance horizontal equity also enhance vertical equity, appeals to both principles can often be used simultaneously. Anti-evasion measures are a prominent example of reforms that facilitate both types of appeals. Middle or lower-income sectors have little opportunity for income tax evasion since taxes are withheld directly from their wages, whereas upper-income sectors receive significant income from nonwage sources and can under-declare those earnings on tax returns. Eliminating exemptions for sources of income accruing disproportionately to the wealthy, such as rents, interest, and capital gains, also enhances both horizontal and vertical equity.

In addition to mobilizing public support, horizontal equity appeals can temper elite antagonism. By definition, reforms that improve horizontal equity affect some taxpayers but not others and may hence avoid provoking broad opposition. Moreover, horizontal equity appeals are one of the few strategies that can generate support from economic elites. Antievasion reforms often elicit support from law-abiding firms, who view tax evasion as unfair competition. Eliminating sectoral tax benefits can generate support from sectors that do not enjoy those benefits. However, where the business community is highly cohesive, support for eliminating sector-specific benefits may be passive at best. Moreover, eliminating sectoral exemptions generally provokes intense opposition from those affected (Ascher, 1984; Olson, 1965).

\section{(b) Benefit-side strategies}

Benefit-side strategies aim to shift attention away from tax increases. I classify these strategies according to who receives the benefits: economic elites who will bear the tax increase, popular sectors, or members of both groups. With a few exceptions, benefit-side strategies explicitly invoke or tacitly rely on the neoliberal imperative of fiscal discipline to draw connections between taxation and benefits.

\section{(i) Linking to popular benefits}

Welfare-state literature advocates linking to popular benefits to minimize public opposition to broad-based taxes (Steinmo, 1993; Wilensky, 2002); I focus on this strategy's potential to mobilize public support for elite-targeted taxes. The logic is similar to tax-side legitimacy appeals. Whereas the latter strategies emphasize a tax increase's inherent legitimacy, linking to popular benefits invokes legitimacy derived from the benefits the tax increase will finance. A prominent example is social spending, which often does not benefit economic elites in developing countries due to means-testing and/or elite preferences for private services. Linking strategies allow the executive to blame legislators who oppose reform for blocking popular benefits. Linking can also create political payoffs for legislators who support reform by letting them share credit for popular programs (Boylan, 1996).

Linking can be achieved through discourse and/or reform design. Discourse alone is the weakest approach. Several techniques make links between taxation and benefits more evident and more credible. First, popular benefits and tax increases can be included within a single reform package so that they are debated simultaneously. Second, if the executive has exclusive initiative on fiscal policy, benefits can be made contingent on tax increases: a reform can be designed such that rejecting the tax increase automatically prevents spending measures from taking effect. Third, revenue from tax increases can be formally earmarked. 
The potential for linking strategies to mobilize public support and hence their likelihood of success depends on features of the associated benefits. The more visible, easily understood, immediate, and broad-based the benefits, the more support they are likely to elicit, and the greater the pressure on legislators to approve tax increases. As emphasized in welfare-state literature, universal benefits generate broader support than means-targeted benefits (Huber \& Stephens, 2012; Pierson, 1994; Wilensky, 2002). However, benefits targeting the poor and groups viewed as particularly deserving or vulnerable may generate broad support based on norms of equity or morality. Public support may also depend on whether citizens perceive that the state has the administrative capacity and probity to ensure that benefits reach intended recipients.

Linking strategies can be more effective than tax-side legitimating appeals for pressuring legislators to approve tax increases. First, popular benefits like social spending will inherently draw greater attention and be perceived as more important by the public than elite-targeted tax reforms, which in and of themselves do not directly affect citizens at large. ${ }^{11}$ Second, to exert electoral control over politicians, voters must perceive negative outcomes, associate them with policy decisions, and identify who is to blame (Arnold, 1990; Hacker \& Pierson, 2005). Tight linking to spending through reform design helps voters follow these cognitive steps by raising awareness of the negative consequences of failing to tax elites, helping voters associate those negative consequences with failed reform, and making it easy to identify reform opponents.

Linking to popular benefits nevertheless has drawbacks. Earmarking may be technically undesirable because it creates budgetary rigidities (Bird \& Jun, 2005) and politically undesirable because it limits discretionary spending. Further, as Ascher (1989: 446) notes, "the directly redistributive nature of taxation becomes all the more obvious" when tax increases are linked to popular benefits. Therefore, like vertical equity appeals, linking to targeted spending may exacerbate elite antagonism.

\section{(ii) Linking to universal benefits: Emphasizing stabilization}

These strategies temper elite antagonism by emphasizing public goods that appeal to elites, such as national security or prestige, ${ }^{12}$ socio-political stability, or economic stability. While these strategies may also generate public support for taxing elites, their role in tempering elite antagonism is particularly important. I focus on economic stabilization, which has been critical in developing countries and is now salient in many developed countries as well.

Emphasizing stabilization aims to convince elites that impending or actual economic crisis is more costly than a heavier tax burden. The observation that economic crisis and especially hyperinflation dispose elites to tolerate increased taxation or other economic reforms is common in literature on structural adjustment (Acuña, 1994; Weyland, 2002).

Various conditions must hold for emphasizing stabilization to succeed. First, elites must perceive instability as imminent. A recent history of crises may increase elites' receptiveness to warnings that economic instability will ensue if fiscal discipline is neglected. Second, elites must perceive instability as costly; fiscal indiscipline may threaten to undermine economic models or governments that economic elites support. If elites do not feel vulnerable, they have little reason to accept a tax increase. Elites may have options for minimizing the costs of instability like moving their assets off shore. Third, elites must be convinced that fiscal discipline cannot be achieved without increasing taxes. Privatization, austerity, reducing state corruption, and international loans or aid must not be perceived as feasible short-term options.

\section{(iii) Compensation}

These strategies provide benefits for economic elites that range from cutting other taxes that economic elites oppose, to subsidies or spending that directly benefits elites, to reforms elites advocate in other policy areas. Compensation is a central idea in fiscal-bargaining literature and market-reform literature. Fiscal-bargaining literature highlights "contracts" in which privileged groups accept tax obligations in exchange for "side payments," including services or other concessions (Levi, 1988: 64). Market-reform literature illustrates that compensation can effectively mitigate elite opposition to reforms in policy areas including trade liberalization and privatization (Corrales, 1998; Schamis, 1999; Etchemendy, 2011; Shleifer \& Treisman, 2000). Kingstone's (2001) concept of "policy bundling" can be viewed as a type of compensation, in which simultaneous or closely sequenced reforms that business supports reduce resistance to reforms that might stimulate opposition if introduced in isolation from a broader reform agenda.

The type and scope of compensations needed to temper elite antagonism depend on their sources of power. If economic elites are organized and cohesive, inclusive compensations may be necessary; if they are fragmented, compensating a few key groups may suffice. Generally, the stronger and more numerous the sources of power, the more significant compensations must be. Earmarking or contingency techniques can formalize the bargain and increase leverage for securing cooperation from politicians who have strong relationships with economic elites.

Compensation can also circumvent investment power. If a tax increase is accompanied by or linked to pro-growth measures, it is less likely to provoke disinvestment or capital flight. Taxes are one of many policies affecting profits, and favorable policies in other areas may offset the costs of higher taxation (Gelleny \& McCoy, 2001; Hacker \& Pierson, 2002).

Potential drawbacks of compensation include unwanted fiscal cost, particularly if revenue is needed for redistributive purposes. The drawbacks of earmarking apply as well, but if compensations are negotiated outside of the tax reform package, elites must perceive a credible commitment and government capacity to deliver the benefits.

\section{CASE STUDIES}

Chile, Argentina, and Bolivia enacted some of Latin America's most extensive market-oriented tax reforms during structural adjustment; by the mid-1990s, their VAT revenue as a percentage of GDP reached European averages. Yet they experienced recurrent revenue needs in subsequent decades, and governments in each country attempted to "go where the money is" by increasing direct taxes. Overall, Argentina legislated more substantial direct tax increases than Chile and Bolivia, contrary to arguments linking institutional instability or weakness to low direct taxation. ${ }^{13}$ I argue elsewhere that the power of economic elites-especially business actors-explains much of this aggregate cross-national variation.

However, reform strategies play an important role in explaining whether governments were able to legislate modest direct tax increases in contexts of strong business power. The four income-tax reforms analyzed below, drawn from a larger 
set of 26 tax-reform packages, were selected to illustrate a variety of strategies and outcomes, holding the strength of business power roughly constant. In each case, business actors had multiple sources of power that posed major obstacles to reform. I first consider two comparatively successful cases of modest tax increases in Chile. Legitimating appeals helped the Lagos administration pass income-tax base-broadening measures in 2001 and 2005, despite business' strong political power. I next consider a case of temporally-limited success from Argentina. Although economic elites were generally much weaker in Argentina, financial-sector elites had strong investment power and political power during the 1990s that created obstacles to taxing interest earnings. Obfuscating incidence allowed the Menem administration to circumvent these obstacles in 1998; however, an inherent drawback associated with the burden-shifting technique-lack of consensus over the actual incidence of the new tax that was created-led to its repeal in 1999. Finally, I examine a case in which strategic errors contributed to resounding defeat: Bolivia's notorious 2003 income tax proposal. The government's insufficient recourse to vertical equity appeals in conjunction with a reform design that was neither patently progressive nor adequately elite-targeted fostered confusion over tax incidence and contributed to protest by popular sectors that the government never intended to tax. ${ }^{14}$

\section{(a) Methods}

I assess how and to what extent reform strategies affected proposal outcomes through process tracing. This qualitative method entails careful use of evidence about context, mechanisms, and sequences, which I draw from in-depth interviews with government officials, politicians, and business leaders, along with primary documents and news articles. The inference process can be formalized as a sequence of tests where each piece of diagnostic evidence increases or decreases the plausibility of the hypothesis under consideration. Methodologists have classified these tests into distinct types based on the logical connections between the evidence and the hypothesis in question as well as implications for rival (or null) hypotheses (Bennett, 2010; Collier, 2011; Goertz \& Mahoney, 2012). Appendix A not only reviews the key ideas in this methodological literature, but also explicitly guides the reader through the multiple processtracing tests that form the basis for my analysis of Chile's 2005 tax reform; process-tracing practitioners usually leave these tests informal and implicit for the sake of presenting readable analytical narratives. The same logic described in Appendix A underpins the analysis of each case study presented below.

In addition to process tracing, I draw on case knowledge to assess what would have happened had the strategy in question been applied differently or not at all (Fearon, 1991; George and Bennett, 2005). This counterfactual analysis is appropriate since policymakers plausibly could have acted differently at the time, and considering this possibility does not entail altering other key elements of the historical record (Goertz \& Mahoney, 2012).

It bears emphasis that the bulk of my causal leverage comes from within-case analysis (and for Chile, comparisons across the two reform cases), not from cross-country comparisons. The value of analyzing cases from multiple countries lies instead in demonstrating the causal importance of reform strategies across different political contexts and levels of development.

\section{(b) Chile's modest successes}

Business's strong political power made it difficult for Chile's center-left governments to legislate tax increases in the 1990s and 2000s. Business power arose primarily from organization and partisan ties (Fairfield, 2010). Chile's prestigious economy-wide business association, the CPC, coordinated lobbying across sectors on sensitive issues like taxation, which business often portrayed as confiscation of property. Further, business was a core constituency for the two right parties, especially the UDI. The UDI's neoliberal, low-tax policy positions drew electoral and financial support from business owners (Luna, 2010). The UDI and dominant business groups were also linked through common origins in the Pinochet dictatorship; government technocrats who later joined the UDI were often board members of business groups that benefited from privatization (Schamis, 1999; Silva, 1996). The right, which was essentially tied with the center-left in the senate during Lagos' administration (2000-05), often took instruction on tax policy directly from business, and business and the right mounted coordinated opposition (interviews: Finance Ministry-a, 2007; Tax Agency, 2005). Increasing taxes therefore entailed costly political battles.

When center-left governments sought to increase the low direct tax burden born by economic elites, they employed multiple strategies, among which equity appeals were often prominent. Equity appeals created political space for incremental advances despite strong business power. As the two cases illustrate, equity appeals undermined business-right opposition more effectively during electoral periods, particularly when inequality became a salient campaign issue.

Authors have argued that Chile's institutionalized party system and stable rules of the game create incentives for cooperation and consensus-building in congress (Flores-Macías, 2010). Yet modest success in these cases cannot be attributed solely to institutions: the right opposed similar reforms on multiple prior occasions.

\section{(i) Anti-evasion reform}

Strategic reform design and associated equity appeals helped the Lagos administration legislate the 2001 Anti-Evasion reform, which secured around 1\% of GDP per year, a major success in the Chilean context though modest in cross-national context. Equity appeals helped the government legislate the reform overall and the income-tax measures, which I emphasize below. However, equity appeals did not preclude extended conflict with business and the right.

Although the former Finance Minister (interview, 2007) observed that "the big money is in direct taxes," the administration decided to raise revenue primarily by fighting indirect-tax evasion to avoid antagonizing business. However, the government also sought to curtail technically unjustified income-tax benefits that facilitated tax avoidance. The administration anticipated that these income-tax base-broadening measures, which targeted large corporations and business owners, would be highly controversial.

To manage business-right opposition, the government employed vertical and horizontal equity appeals. In terms of vertical equity, President Lagos stressed that evasion favored the rich at the expense of the poor (E1 Mercurio 2000a, 2001a). He recalled: "I would say: when you go to buy a kilo of bread, you pay $18 \%$ VAT. You have no trick, no mechanism for paying less. The poor pay all their taxes. And it is just [fair] that the rich pay all their taxes," (interview, Lagos, 2006). Regarding horizontal equity, the government asserted: "Tax evasion 
entails great inequity between those who comply with their tax obligations and those who do not. ... from an ethical perspective, no one can oppose an initiative that pursues compliance with the law," (Lagos \& Eyzaguirre, 2000). Chile's center-left governments routinely linked tax increases to social spending; this reform was no exception. However, the Anti-Evasion reform's inherent legitimacy was so compelling that "the discussion was more about ethics than the purpose of the funds," (interview, Lagos, 2006).

The government extended these appeals to the income-tax measures. This approach entailed equating tax avoidance with tax evasion in terms of impropriety, even though avoidance does not break the law. A Private Sector-a (2005) informant complained: "[the government] deliberately mixed and confused tax avoidance, tax planning, evasion, and immorality... there was a policy of confusing language in order to legitimate persecution of legal practices." Framing the income-tax measures as curtailing morally unacceptable behavior rather than simply raising revenue aimed to delegitimate business-right opposition. Executive-branch officials consistently denied that the reform contained tax increases. When asked why the government had initiated a tax reform, the Finance Minister replied: "I do not agree that this is a tax reform. Fundamentally what we have designed is a campaign against evasion," (El Mercurio, 2000b).

Available evidence suggests that equity appeals helped the government maneuver the package through congress. To justify opposing the income-tax measures, the right was in the disadvantageous position of explaining the subtle difference between evasion and avoidance; the vast majority of citizens had no experience with these practices. Key government informants attested that the strategy put pressure on the right and created space for legislative modifications that otherwise would not have been possible. The former senate president asserted that the right was in an "absolutely defensive position... they were looking for any possible argument" against the reform (interview, PDC, 2007). Similarly, the former tax agency director (interview, 2005), who participated in multiple negotiations on the bill, recalled: "Lagos was in the press every day saying everybody must pay taxes. ...The right asked the government to stop that, because they were associated with illegal things, being selfish, fraud. It was a political battle that I think we won."

More decisive evidence comes from statements by right politicians. The two right senators on the Finance Committee told the press that they abstained instead of voting against the reform because: "otherwise, President Lagos would have said that the opposition is against combatting tax evasion," (El Mercurio, 2001b). One of these senators later elaborated: "the [bill's] title-evasion - it suggests going after criminals. It's very difficult to oppose someone who presents that framing," (interview, Prat, 2005). Ultimately, the government secured abstentions on the reform package - tacit acceptance-from seven right senators.

However, equity appeals were not sufficient to pass the income-tax measures. This strategy failed to temper business antagonism toward these measures, although business did support many of the strictly anti-evasion initiatives. And efforts to mobilize public support did not compel the right to break ranks with business, despite the President's threats to make the reform an issue in the parliamentary elections scheduled for the end of the year (El Mercurio, 2000a). The right held up the reform in the Senate until the executive negotiated concessions that placated business. ${ }^{15}$ And most of the right senators voted against the two most controversial of the seven income-tax measures during the line-item vote after the overall reform initiative was approved. 16

Why did the government's strategy have a limited, though still important, effect on the right? One possibility, which cannot be directly assessed for lack of public opinion data, is that equity appeals did not generate strong public support. Yet the government did not include the reform in its private polls given an expectation of overwhelming support for fighting evasion (interview, FDD, 2012), and evidence presented above suggests that right legislators perceived public receptiveness to the government's framing strategy. A more compelling explanation for the limited effect of equity appeals in this case lies in the nature of voter-party linkages and the timing of reform. First, the UDI's segmented electoral strategy gave it leeway to defend the interests of its core constituency without necessarily alienating its mass base. Whereas the UDI attracts upper-income voters through programmatic linkages, it attracts lower-income voters through district-level clientelism and charismatic appeals, not economic policies (Luna, 2010). Therefore, the UDI could afford to ignore mass public opinion on tax equity without necessarily incurring electoral costs. Second, the parliamentary elections were many months away, giving voters ample time to forget the right's position on the Anti-Evasion reform and the right ample time to draw attention to other issues. Despite these limitations, the case evidence along with the governing coalition's prior difficulties legislating similar reforms suggests that without equity appeals, the right's bargaining position would have been stronger and the government would have had to make even greater concessions.

\section{(ii) Stockholder tax subsidy}

Legitimating appeals helped the government legislate another income-tax base-broadening measure in 2005. Given the unusually high salience of inequality during a presidential campaign, vertical equity appeals generated much stronger electoral incentives for the right to deviate from its core business constituency's preferences.

The tax benefit known as " 57 bis," inherited from the dictatorship, constituted a perpetual government subsidy for owners of new-issue stocks, most of whom belonged to the wealthiest percentile of taxpayers. The Lagos administration considered eliminating 57 bis in the Anti-Evasion reform, but it was judged infeasible given strong business-right resistance (interview, Finance Ministry-c, 2005). Efforts to eliminate the exemption in the 1990s also failed.

An opportunity for reform arose in 2005 due to unanticipated electoral competition from the right on the issue of inequality. When Chile's Catholic bishops forcefully denounced the country's persistent inequality, right-coalition presidential candidate Lavín blamed lack of progress on the center-left: "Inequality, Mr. President, continues. ...There is a Chile that grows, but it is for the few, and the great majority have not yet benefited," (El Mercurio, 2005a). Inequality became the central campaign issue during the following weeks. President Lagos responded with a challenge: "The infamous article 57 bis represents a tremendous support for inequality... Instead of just talking, why don't we agree to eliminate 57 bis in less than 24 hours?" (El Mercurio, 2005b).

This vertical equity appeal proved highly successful. In contrast to the Anti-Evasion reform, debate on 57 bis was minimal. Lavín accepted the government's challenge: “...we are all for equity. Let's do it," (El Mercurio, 2005c), and right legislators followed his lead, disregarding business's policy 
preferences. The bill received nearly unanimous congressional approval.

The salience of inequality during the campaign raised the anticipated political costs to the right of defending business interests. Opposing the reform would have undermined Lavin's credibility and validated the government's claim that the right was the main obstacle to reducing inequality in Chile. With only six months until the election and public attention focused on inequality, voters might well have remembered the coalition's policy position and punished Lavín at the polls. Lavín's advisors attributed Lagos' narrow 1999 victory to the right's rejection of a popular labor-rights bill sent to congress during the campaign; this episode weighed heavily in the right's analysis of the 2005 reform (El Mercurio, 2005d, 2005e). Comparing the two reforms, a Lavín advisor declared: "The center-right is not willing to fall into the 1999 trap again," (El Mercurio, 2005e). Meanwhile, framing the tax increase as hurting the middle class, a tactic regularly used by the right, was not feasible because the reform patently targeted elites. Tax agency data showed that $0.5 \%$ of adults received $72 \%$ of the tax expenditure associated with 57 bis. As a government informant recalled: "it was a pure transfer of resources to rich people; there was no way to argue differently. ... It was not possible for the right to oppose the reform after making that argument about inequality," (interview, Finance Ministry-b, 2005). An UDI (interview, 2005) informant candidly acknowledged that electoral concerns motivated the right to accept the reform: "the opposition demonstrated that this time it would accept things that usually it was not disposed to accept so as not to harm the presidential option-in this case it would do something popular, perhaps populist." The counterfactual therefore seems clear: had the government attempted to eliminate 57 bis without the high-profile equity appeal, the right would have blocked the reform as it had on multiple prior occasions.

\section{(c) Argentina's temporally-limited success: Tax on corporate debt}

Argentine policymakers faced different constraints that precluded eliminating a regressive income-tax exemption for interest earnings in the 1990s: bank-depositors' investment power, as well as the banking association's political power. ${ }^{17}$ Obfuscating incidence helped government technocrats enact an alternative reform intended to accomplish the same goal, yet their success was short-lived given lack of consensus regarding the actual incidence of the new tax, a drawback of the burden-shifting technique employed.

Argentine economists concurred that interest earnings on savings accounts and corporate bonds should be taxed. The income-tax exemption entailed a nontrivial revenue loss and amounted to a state subsidy for corporate debt. Politicians across party lines also agreed that interest should be taxed; Argentina has no electorally-relevant right party, and legislators often complained that the exemption unfairly favored the rich.

However, there was widespread concern that eliminating the tax exemption would provoke disinvestment from the banks. Savings in Argentina were physically mobile as well as electronically mobile; wealthy Buenos Aires residents could easily open tax-free savings accounts in Uruguay's nearby financial centers. Pervasive lack of confidence in the security of deposits, due to Argentina's history of hyperinflation, bank failures, and state interventions that confiscated savings, exacerbated potential incentives to move mobile assets abroad. The perceived disinvestment threat was particularly troublesome because massive withdrawals would have destabilized not only the banks, but also the broader economy; the financial sector was central to Argentina's economic model in the 1990s while the peso was pegged to the dollar.

Meanwhile, the financial sector enjoyed strong political power during the 1990s thanks to recruitment into government and informal ties to policymakers. The Secretary of Finance during Menem's first administration was a former bankingassociation president, and economists from think tanks linked to the financial sector were appointed to the Economy Ministry and the Central Bank. The banking association defended the interest-earnings exemption and used its political power to lobby against reform for fear of losing customers.

During Menem's second administration, Economy Ministry technocrats designed a reform to tax interest earnings that circumvented these constraints. They proposed a tax on corporate debt, which would tax interest payments made by firms, rather than interest earned by individuals. This design obfuscated incidence via burden-shifting. Technocrats argued that the new tax would have the same incidence as including interest earnings in the personal income tax base, because the tax burden would be transferred from corporate debtors to individual creditors through interest rates. If interest were included in the income tax base, banks would have to offer higher rates of return to their depositors, which they would compensate by charging higher interest rates on loans to firms. Applying a tax on corporate debt would have the same outcome: higher effective interest rates on loans to firms. The new tax was intended to make taxation of interest earnings less visible to investors, and hence less likely to motivate flight from the banks and less likely to stimulate opposition from the financial sector and legislators.

Obfuscating incidence allowed the executive to successfully legislate the reform in 1999. The financial sector accepted the new tax with minimal resistance (interview, Economy Ministry-a, 2006). To win the sector's acquiescence, Economy Ministry officials explicitly presented the reform as an alternative to eliminating personal income tax interest exemption: "we said, 'look, we came up with this tax on debt because what we thought about doing before was eliminating the exemption,' and of course, they told us 'yes, that would be much worse than the tax on debt," (interview, Economy Ministryb, 2006). Financial-sector informants confirmed that assessment (ABA, 2006; ADEBA, 2006). The tax on corporate debt also precluded resistance from governing-coalition legislators who feared that eliminating the income-tax exemption would cause capital flight. References to any potential negative impact on bank deposits were essentially absent from discussion of the tax in the press and in congress. In fact, few legislators understood that the tax burden would be transferred to interest earnings (interview, Economy Ministry-a, 2006); it was perceived instead as a corporate tax increase. A longtime senator with tax expertise recalled: "It was like learning Aramaic or some other extinct ancient language; no one understood what it was about," (interview, Baglini, 2006).

Despite the legislative success, the obfuscation strategy had a major drawback that led to the reform's untimely demise: the attempt to exploit burden-shifting created uncertainty about the actual incidence of the new tax. Economists from the opposition coalition did not believe the assumptions needed to make taxing debt equivalent to taxing interest earnings actually held (interviews: Economy Ministry-d, 2006; Economy Ministry-c, 2007). They felt the tax on debt imposed an undue burden on small businesses, which already faced much higher interest rates than big firms. Accordingly, the tax was phased-out after the opposition won power in 1999. 
While the new government's economists agreed that interest should be taxed, continued concerns regarding investment power precluded reform. Interest earnings remain untaxed as of this writing. Strategic drawbacks aside, however, this evidence supports a strong counterfactual: no obfuscation, no interest-earnings taxation.

\section{(d) Bolivia's failed income tax initiative}

Whereas an inherent strategy limitation undermined Argentina's tax on debt, poor reform design and inadequate vertical equity appeals - the natural strategy choice - ensured the failure of Bolivia's 2003 income tax proposal. Instead of mobilizing public support, the initiative incited unanticipated popular protest.

President Sánchez de Lozada (2002-03) faced countervailing pressures from economic elites and popular sectors. Economic elites enjoyed strong political power during the early 2000s prior to indigenous leader Evo Morales' electoral victory. Elites had extensive informal ties to the traditional parties that together held a majority in congress (MNR, and MIR, and ADN), and strong encompassing organizations facilitated collective action by business actors (Conaghan \& Malloy, 1994; Eaton, 2007; Gamarra \& Malloy, 1995). Business associations denounced tax increases, arguing that the large, primarily indigenous informal sector should be incorporated into the tax base instead (interview, CEPB, 2006). On the other hand, highly-mobilized popular sectors demanded redistributive policies and political inclusion. During this period, Bolivia experienced a "continuous cycle of protest" (Barr, 2005) involving indigenous organizations, civic associations, labor unions, and Morales' indigenous-left party. These groups pressed different demands, but all rejected the neoliberal economic model and the exclusionary traditional party system.

Given the likelihood of mass protest, broad-based consumption taxes were not an option for closing the budget deficit that Sánchez de Lozada inherited when he took office. This reality along with technical considerations compelled the government to propose creating an individual income tax, ${ }^{18}$ notwithstanding economic elites' strong political power. The tax would apply a flat rate of $12.5 \%$ on income exceeding a fixed threshold, such that the effective tax rates paid would be progressive, rising from 3\% to $11 \%$ (interview, Finance Ministry-d, 2006). Although technocrats recommended a threshold of four to six times the minimum wage, Sánchez de Lozada sent the proposal to congress with a threshold equivalent to twice the minimum wage to leave room for bargaining with legislators (interview, Finance Ministry-e, 2007). Yet given the tiny size of the formal sector, the proposed tax would still affect fewer than $6 \%$ of Bolivians.

The business associations denounced the income tax as recessionary and prepared to lobby against it (La Razón, 2003b, 2003e; El Deber, 2003). But ironically, popular protest against the tax forced the government to withdraw the proposal before business opposition gained momentum. Police, teachers' unions, and university students clashed with the military for two days in the capital, while indigenous organizations and future president Morales condemned the tax and planned additional demonstrations (La Razón, 2003a, 2003c). Labor leaders lamented: "once again the burden of economic responsibility is placed on the shoulders of the workers," (La Razón, 2003c). Indigenous leader Quispe even decried that peasants would ultimately bear the tax burden (La Razón, 2003e). Notwithstanding these assertions, most of the protesters earned salaries below the threshold and would not have been affected by the tax (interviews: Finance Ministry-d, 2006, Finance Ministry-e 2007).

Many factors, including accumulated grievances and broad anti-government sentiments, helped catalyze the income-tax protest. However, the government's strategic errors played a critical role. The reform design undermined the inherent legitimacy it should have enjoyed, and the government did not sufficiently emphasize vertical equity. Because the tax had a flat rate instead of a progressive bracket structure, it was incorrectly perceived as regressive and unfair. And the threshold of only twice the minimum wage suggested that the tax was broad-based, even though the vast majority earned far less than that threshold. Media coverage reinforced these misperceptions. A prominent newspaper headline read: "Everyone alike will pay $12.5 \%$ of their salary," (La Razón, 2003f). Even the government's own statements portrayed the tax as broadbased. Although Sánchez de Lozada explained that the tax would affect the rich rather than the poor, he stated that it would touch middle-income sectors: "we have asked the middle class to assume this sacrifice," (La Razón, 2003d). This "middle class" in reality comprised a tiny, privileged group of highly-paid wage-earners and independent professionals.

A visibly progressive, more narrowly elite-targeted tax combined with concerted equity appeals could have prevented the proposal from becoming a target of mass opposition. In fact, a 2004 wealth tax initiative that satisfied these criteria elicited no popular condemnation. ${ }^{19}$ Protest may still have occurred against the stagnant public-sector wages in the 2003 budget that was simultaneously sent to congress, but the government probably would not have had to withdraw the tax proposal. In retrospect, government technocrats recognized these errors. One informant asserted: "If we had sent it [the bill] with [a threshold of] six [minimum wages], a lot of arguments [against the tax] would have fallen apart automatically," (interview, Finance Ministry-d, 2006). Another lamented the government's insufficient efforts to explain the tax to the public (interview, Finance Ministry-e, 2007).

Although a more targeted tax would have raised less revenue, governments could have broadened the base and/or increased the rate in the future; Chilean governments often used this incremental approach. Instead, the failed proposal gravely damaged prospects for implementing an income tax in Bolivia. Technocrats in the Mesa and Morales administrations agreed that Bolivia needs a personal income tax, but no government has dared introduce a tax that in any way resembles Sánchez de Lozada's failed initiative, however narrow the base, for fear of renewed protest (interviews: Finance Ministry-f, 2007, Finance Ministry-h 2006).

In the absence of popular protest, Sánchez de Lozada would still have faced a battle with business and the traditional political parties. However, in Sánchez de Lozada's (interview, 2010) own view, his authority over the governing coalition at that time was strong enough to force a modest, patently elite-targeted tax through congress.

\section{(e) Comparative overview}

Business power was strong in each of the cases examined, although the types and sources of power differed. Strong business power posed major obstacles to direct tax increases. In Chile and Argentina, governments had considered incometax base-broadening initiatives in prior years, but ruled them out as infeasible given active business resistance and/or fears of disinvestment. In Bolivia, business also had strong sources of power that made income-tax reform difficult. 
I have argued that reform strategies played an important role in influencing proposal outcomes. Chile achieved modest successes with the help of carefully-crafted equity appeals, although the nature of right party-voter linkages tempered their impact. These appeals proved more effective when equity became highly salient during electoral campaigns, giving politicians stronger incentives to worry about public opinion. Argentina achieved temporally-limited success at taxing interest-earnings. Obfuscating incidence tempered the powerful financial sector's resistance to reform, but lack of consensus over the true incidence of the new tax contributed to its subsequent demise. And in Bolivia, inadequate equity appeals and insufficient elite-targeting contributed to the income-tax initiative's dramatic failure.

It is worth stressing that other factors contributed to these outcomes. Business and the right in Chile accepted incometax base-broadening measures not just because the government's equity appeals undermined their resistance, but also because the government made concessions. Argentina's tax on debt might not have been so readily overturned had the country's party system and institutions created stronger incentives for cross-partisan compromise and resolute policymaking, as in Chile. ${ }^{20}$ And the protest that killed Bolivia's income-tax proposal reflected widespread discontent with the government and a party system in upheaval, as well as misperceptions regarding who would pay the tax. Yet none of these factors negate the causal contribution of the reform strategies employed. The Chilean government likely would have been forced to make even greater concessions without equity appeals. Given the consensus that interest earnings should be taxed, Argentine policymakers would not have been motivated to repeal the tax designed to obfuscate incidence had they not harbored serious concerns over who actually bore the burden. And it is hard to imagine that Bolivian protesters would have included among their grievances a tax that narrowly and visibly targeted the very economic elites whose dominance and privilege they sought to challenge.

A common theme emerging from the case studies is the importance of incidence perceptions and potential difficulties or tradeoffs involved in managing them. In Argentina, taxpayers' lack of awareness and legislators' inability to understand tax incidence facilitated legislation of the tax on debt, yet lack of consensus on incidence among technocrats led to the reform's repeal. In Bolivia, popular misperceptions about incidence sealed the income tax's demise. Yet a patently progressive, highly-targeted tax could have elicited more intense opposition from economic elites. In Chile, business recognized that income tax base-broadening measures would increase their tax burden, notwithstanding the government's emphasis on fighting evasion. Yet citizens' ignorance about complex tax issues probably made them more receptive to the government's legitimating appeals than to business's explanations of the difference between tax evasion and tax avoidance.

\section{CONCLUSION}

Building direct tax capacity in developing countries is a question of substantial theoretical interest and practical importance, particularly when income and profits are heavily concentrated and consumption is heavily taxed. This paper advances theory on direct tax reform by explicating two types of power that allow economic elites to shape policy outcomes: political power and investment power; identifying two mechanisms for circumventing associated obstacles to reform: mobi- lizing public support, or tempering elite antagonism; relating those mechanisms to specific strategy options; and assessing when particular strategies will be more or less appropriate and effective. My framework complements research on taxation that applies structural, historical, or institutional approaches by focusing on strategies, a variable that policymakers can readily manipulate. I argue that although significant advances are unlikely when economic elites have strong political and/or investment power, reform strategies can help governments enact incremental direct tax increases. The room for maneuver these strategies create may be narrow. Yet the modest revenue gains secured can make a difference for governments struggling to maintain fiscal solvency and/ or expand tenuous social safety nets.

This research not only advances theory, but also provides practical tools and guidelines for policymakers. The framework presented can serve as a basis for evaluating which options are more or less feasible and appropriate, depending on the nature of the government's revenue needs as well as the types of power economic elites possess. Appendix B summarizes the strategies, associated techniques, potential limitations, and contextual factors affecting success. Three general policy implications arise. First, incremental reform proposals may prove more successful than ambitious reform initiatives. Second, the more strategies a government can apply simultaneously, the better the prospects for success, particularly when economic elites have strong and multiple sources of power. And third, one size does not fit all: reform design and reform strategies must be tailored to the particular context at hand.

Regarding debates on framing and policy design, I find that both elements matter to reform outcomes. Scholars have argued that framing plays a central role in US tax politics, particularly when strong moral values are invoked (Birney et al., 2008; Graetz \& Shapiro, 2005). This paper provides additional evidence from developing countries indicating the importance of framing. Equity appeals contributed to Chile's modest direct tax reform successes. By framing tax avoidance as immoral and unfair, the Lagos administration put business and the right on the defensive and created some political space for curtailing technically unjustified incometax benefits. In contrast, inconsistent and inadequate equity appeals contributed to Bolivia's income tax failure; the government's communication campaign failed to meet the minimum requirement of assuring the broader public that it would not pay the tax, let alone convincing them that the tax was a just and equitable policy appropriate for the highly unequal country.

Yet as other authors have noted, policy design is at least as important as framing for managing reactions to reform (Hacker \& Pierson, 2005). Almost all of the tax reform strategies are closely associated with either the choice and design of the tax measure itself, or the design of the larger reform package. Argentina's tax on debt is a case in which design alone sufficed to enact (if not sustain) reform. The Chilean and Bolivian cases show that policy design and framing are often integrally related and mutually reinforcing. In Chile, equity appeals would have been less effective had the tax reforms not clearly conformed to this principle. In Bolivia, the proposed income tax's lack of overt progressivity probably would have undermined even well-formulated and consistent equity appeals.

Regarding literature on market reform, this paper suggests that the politics of policy change can be much more variable than often assumed. Authors often categorize policy areas and the political dynamics they engender based on their distributional effects (Schneider, 2004; Arce, 2005). Taxation differs 
from other policy areas like trade liberalization or capital account liberalization, since tax increases impose much more predictable and immediate losses. Yet even within the specific policy domain of taxing economic elites, politics vary widely, depending on which groups are affected and what sources of power they possess, as well as how governments propose to tax them and what reform strategies they employ. These findings confirm Pierson's (1993: 625) expectation that politics cannot be neatly categorized across aggregate policy types. Instead, a specific policy may stimulate multiple political responses that depend on the details of its design as well as multiple context-specific variables. Future research on building tax capacity in developing countries could therefore benefit from disaggregating taxation to a more significant extent and conducting more comparative case studies, rather than focusing on aggregate reform indices or revenue data.

Finally, this paper contributes to recent research on institutional change. Mahoney and Thelen (2010) and Hall (2010) advocate greater attention to the role of power and conflict in bringing about institutional change; my framework brings those dimensions to the forefront of analysis. Hall (2010: 219) also calls for more research on how processes of institutional change vary across issue domains; this paper complements that agenda by providing theory and evidence on how such processes may vary within a single, substantively critical issue domain - taxation.
However, my analysis highlights limitations in Mahoney and Thelen's (2010) innovative framework for analyzing gradual institutional change. The authors distinguish four types of change, including displacement: replacing existing rules by new ones, and layering: adding new rules without removing old rules. They theorize that layering occurs in political contexts where strong veto actors defend existing rules, whereas displacement occurs when veto possibilities are weak. However, the distinction between layering and displacement is not necessarily fundamental to the politics of gradual institutional change, nor do these concepts necessarily align with political contexts as hypothesized. Altering tax systems may entail layering, for example, introducing new taxes into the existing system, as in Argentina and Bolivia. Or it may entail displacement, for example, rewriting existing tax laws to eliminate exemptions, as in Chile. Yet both modes of change occurred in contexts of strong veto possibilities posed by powerful economic elites. The politics of institutional change and strategies for achieving it certainly varied across these cases, but in ways that Mahoney and Thelen's framework does not capture. Future research on institutional change might therefore benefit from incorporating additional complexity and context specificity into models, as well as assessing to what types of institutions theories will be most applicable.

\section{NOTES}

1. The Interamerican Development Bank, the Woodrow Wilson Center, the Economic Commission for Latin America and the Caribbean, and the UK Department for International Development have shown growing interest in strengthening progressive taxation in developing countries.

\section{Exceptions include Boylan (1996) and Weyland (1997).}

3. Flores-Macías (2012) finds that in some contemporary cases, internal war may help build direct tax capacity. However, this observation provides little guidance for policymakers in peaceful states.

4. See also www.wilsoncenter.org/event/taxation-and-equality-latinamerica. For recent views to the contrary, see Bird and Zolt (2005).

5. Goñi, López, and Servén's (2011) excellent analysis of fiscal redistribution in Latin America does not adequately address this critical revenueraising role of progressive direct taxation.

6. Pierson's (1994) work on welfare-retrenchment strategies serves as a model in many of these regards.

7. On structural power, see Block (1977), Lindblom (1977), Przeworski and Wallerstein (1988), Winters (1996) and Hacker and Pierson (2002). On instrumental power, see Mills (1956), Miliband (1969) and Hacker and Pierson (2002).

8. I borrow the term obfuscation from Pierson (1994: 19-22), who elaborates a similar class of strategies to achieve a different goal: welfare state retrenchment.

9. The VAT, which is hidden within the final price of the good, is often described as a low-visibility tax. However, the VAT is nonetheless frequently subject to consumer protest (Moore, 2004: 312). On this point as well as an extensive discussion of conceptualizing and measuring tax visibility, see Martin and Gabay (2007).
10. See for example: Campbell, Converse, Miller, and Stokes (1960), Roemer (1999) and Luna (2010).

11. Hirschman (1973: 267, 217) draws this conclusion regarding land taxes. Likewise, US public opinion on taxes paid by the wealthy is described as "low intensity" (Graetz \& Shapiro, 2005: 254) or "remarkably superficial" (Bartels, 2008: 176).

12. Emphasizing national security helped South African governments secure elite cooperation to finance war efforts (Lieberman, 2003: 140-148). In post-communist countries, appealing to national prestige facilitated tax reforms required for EU membership (Appel, 2006).

13. Melo (2007), drawing on Tommasi and Spiller (2000) and Levitsky and Murillo (2005). Chile is considered to have stronger and more stable institutions than Argentina and Bolivia. Regarding other institutional variables that may affect prospects for legislating reforms, Chile and Argentina both have executives with strong institutional prerogatives, all three countries had party-oriented electoral systems that promoted discipline in congress, and none of the countries had institutions that fostered legislative gridlock during the studied period.

14. Although relative success across these cases appears correlated with institutional and party system strength and stability, the relationship does not hold across the larger set of cases from which these examples are drawn. These factors therefore provide at most incomplete explanations.

15. Business did not embrace the final version of the reform, but informants agreed that it was much more acceptable than the original bill (interviews: CChC, 2005; CPC, 2005; Private Sector-b, 2005; SOFOFA, 2005).

16. In Chile, congress first votes "in general" on reforms (yes or no); if an approved reform is multifaceted, a second vote "in particular" (line-item) may be held in which each measure is voted on separately.

17. See Fairfield (2010) for further discussion of these sources of power. 
18. This tax was eliminated in 1986 given weak administrative capacity, which subsequently improved (interview, Finance Ministry-g, 2007). The absence of a personal income tax facilitated generalized tax evasion. Businesses could simultaneously avoid the corporate tax and transfer profits to owners and executives tax-free by paying inflated salaries (interviews: Finance Ministry-d, 2006; Finance Ministry-f, 2007).
19. However, the wealth tax provoked intense business opposition, a drawback of highly targeted, visibly progressive taxes.

20. See Cox and McCubbins (2002) and Flores-Macías (2010).

\section{REFERENCES}

Acuña, W. (1994). Politics and economics in the Argentina of the nineties. In W. C. Smith, C. H. Acuña, \& E. Gamarra (Eds.), Democracy, markets, and structural reform in Latin America. Miami: University of Miami, North-South Center.

Alvaredo, F. (2010). The rich in Argentina over the twentieth century. In A. Atkinson, \& T. Piketty (Eds.), Top incomes: A global perspective. Oxford: Oxford University Press.

Appel, H. (2006). International imperatives and tax reform: Lessons from postcommunist Europe. Comparative Politics, 39, 43-62.

Arce, M. (2005). Market reform in society. University Park: Pennsylvania State University.

Arnold, R. D. (1990). The logic of congressional action. New Haven: Yale University Press.

Ascher, W. (1984). Scheming for the poor: The politics of redistribution in Latin America. Cambridge: Harvard University Press.

Ascher, W. (1989). Risk, politics, and tax reform: Lessons from some Latin American experiences. In M. Gillis (Ed.), Tax reform in developing countries. Durham: Duke University Press.

Barr, R. (2005). Bolivia: Another uncompleted revolution. Latin American Politics and Society, 47(3), 69-90.

Barreix, A., Roca, J., \& Villela, L. (2006). Política fiscal y equidad: Resumen ejecutivo. In A. Barreix, J. Roca, \& L. Villela (Eds.), $\mathrm{La}$ equidad fiscal en los países Andinos (pp. 2-65). Washington, DC: DFID, Banco Interamericano de Desarrollo, Comunidad Andina.

Bartels, L. (2008). Unequal democracy. Princeton: Princeton University Press.

Bates, R., \& Lien, D. D. (1985). A note on taxation, development, and representative government. Politics and Society, 14(1), 53-70.

Bennett, A. (2010). Process tracing and causal inference. In H. Brady, \& D. Collier (Eds.), Rethinking social inquiry (2nd ed.). Lanham: Rowman and Littlefield.

Block, F. (1977). The ruling class does not rule. Socialist Revolution, 33, 6-27.

Bird, R., \& Jun, J. (2005). Earmarking in Korean theory and practice. In: International tax program papers No. 513. Institute for International Business, Rotman School of Management, University of Toronto.

Bird, R., \& Zolt, E. (2005). Redistribution via taxation: The limited role of the personal income tax in developing countries. UCLA Law Review, $1628-1695$.

Birney, M., Shapiro, I., \& Graetz, M. (2008). The political uses of public opinion. In I. Shapiro, P. A. Swenson, \& D. Donno (Eds.), Divide and deal (pp. 298-340). New York: New York University Press.

Boylan, D. (1996). Taxation and transition: The politics of the 1990 Chilean tax reform. Latin American Research Review, 31(1), 7-31.

Brautigam, D., Fjeldstad, O., \& Moore, M. (Eds.) (2008). Taxation and state-building in developing countries. New York: Cambridge University Press.

Campbell, A., Converse, P. E., Miller, W. E., \& Stokes, D. E. (1960). The American voter. New York: John Wiley.

Conaghan, C., \& Malloy, J. (1994). Unsettling statecraft: Democracy and neoliberalism in the Central Andes. Pittsburgh: University of Pittsburgh Press.

Collier, D. (2011). Understanding process tracing. Political Science and Politics, 44(4), 823-830.

Collier, D., Brady, H., \& Seawright, J. (2010). Sources of leverage in causal inference: Toward an alternative view of methodology. In H. Brady, \& D. Collier (Eds.), Rethinking social inquiry (2nd ed., pp. 161-199). Lanham: Rowman and Littlefield.

Collier, D., LaPorte, J., \& Seawright, J. (2012). Putting typologies to work: Concept formation, measurement, and analytical rigor. Political Research Quarterly, 65, 217-232.

Corrales, J. (1998). Coalitions and corporate choices in Argentina, 19761994: The recent private sector support of privatization. Studies in Comparative International Development, 32(4 Winter), 24-51.
Cox, G., \& McCubbins, M. (2002). The institutional determinants of economic policy outcomes. In Haggard, \& McCubbins (Eds.), Presidents, parliaments, and policy. New York: Cambridge.

Eaton, K. (2007). Backlash in Bolivia: Regional autonomy as a reaction to indigenous mobilization. Politics and Society, 35(1), 71-102.

Eaton, K. (2002). Politics and economic reforms in new democracies. University Park: Pennsylvania State University Press.

El Deber (2003, February 6). Otro impuesto al salario generará más evasion. Santa Cruz, Bolivia.

El Mercurio, (2000a, September 10). Lagos recogió observaciones de empresarios". Santiago, Chile.

El Mercurio (2000b, October 8). Un dolor para crecer. Santiago, Chile.

El Mercurio (2001a, March 14). Lagos pidió apoyo al proyecto. Santiago, Chile.

El Mercurio (2001b, March 15). Avance trámite de evasión tributaria. Santiago, Chile.

El Mercurio (2005a, May 7). Presidente, deje que Soledad y Michelle se defiendan solas. Santiago, Chile.

El Mercurio (2005b, May 10). Lagos reta a Alianza a derogar exención tributaria en 24 horas. Santiago, Chile.

El Mercurio (2005c, May 11). Gobierno no afloja en disputa con Lavín. Santiago, Chile.

El Mercurio (2005d, May 12). Joaquín Lavín y las fórmulas para enfrentar la desigualdad. Santiago, Chile.

El Mercurio (2005e, May 13). Nuevo Escenario de Campaña. Santiago, Chile.

Etchemendy, S. (2011). Models of economic liberalization. New York: Cambridge University Press.

Fairfield, T. (2010). Business power and tax reform: Taxing income and profits in Chile and Argentina. Latin American Politics and Society, 52(2), 37-71.

Fearon, J. D. (1991). Counterfactuals and hypothesis testing in political science. World Politics, 43(2 January), 169-195.

Flores-Macías, G. (2010). Statist vs. pro-market: Explaining leftist governments' economic policies in Latin America. Comparative Politics, 42(4), 413-433.

Flores-Macías, G. (2012). The political economy of Colombia's "democratic security taxes". Working paper. Latin American Studies Association conference, San Francisco, May 23-26.

Graetz, M., \& Shapiro, I. (2005). Death by a thousand cuts. Princeton: Princeton University Press.

Gamarra, E., \& Malloy, J. (1995). The patrimonial dynamics of party politics in Bolivia”. In S. Mainwaring, \& T. Scully (Eds.), Building democratic institutions: Party systems in Latin America (pp. 399-433). Stanford: Stanford University Press.

Gelleny, R., \& McCoy, M. (2001). Globalization and government policy independence: The issue of taxation. Political Research Quarterly, 54(3), 509-529.

George, A., \& Bennett, A. (2005). Case studies and theory development in the social sciences. Cambridge, MA: MIT Press.

Gibson, E. (1996). Class and conservative parties. Baltimore: Johns Hopkins University Press.

Goertz, G., \& Mahoney, J. (2012). A tale of two cultures: Qualitative and quantitative research in the social sciences. Princeton: Princeton University Press.

Gomez-Sabaini, J. C. (2006). Cohesión social, equidad y tributación. Santiago, Chile: CEPAL.

Gomez-Sabaini, J. C., Jiménez, J. P., \& Rossignolo, D. (2012). Imposición a la renta personal y equidad en América Latina. Santiago, Chile: CEPAL.

Goñi, E., López, H., \& Servén, L. (2011). Fiscal redistribution and income inequality in Latin America. World Development, 39(9), 15581569. 
Hacker, J., \& Pierson, P. (2002). Business power and social policy: Employers and the formation of the American welfare state. Politics and Society, 30(June), 277-325.

Hacker, J., \& Pierson, P. (2005). Abandoning the middle: The Bush tax cuts and the limits of democratic control. Perspectives on Politics, 3(1), 33-53 (March).

Hall, P. (2010). Historical institutionalism in rationalist and sociological perspective. In J. Mahoney, \& K. Thelen (Eds.), Explaining Institutional Change. New York: Cambridge University Press.

Hirschman, A. O. (1973). Journeys toward progress. New York: Twentieth Century Fund.

Huber, E., \& Stephens, J. D. (2012). Democracy and the left. Chicago: University of Chicago Press.

International Monetary Fund (IMF) (2011). Western hemisphere: Shifting winds, new policy challenges. Washington, DC: IMF.

Jacobs, L., \& Shapiro, R. (2000). Politicians don't pander. Chicago: University of Chicago Press.

Kingstone, P. (2001). Why free trade "losers" support free trade: Industrialists and the surprising politics of trade reform in Brazil. Comparative Political Studies, 34 (9 November), 986-1010.

Kurtz, M. (2009). The social foundations of institutional order: Reconsidering war and the "resource curse" in third world state building. Politics and Society, 37(4), 479-520.

Lagos, R., \& Eyzaguirre, N. (2000, August 24). Mensaje 178-342: Proyecto de ley que establece normas legales para combater la evasion tributaria. Santiago, Chile.

La Razón (2003a, February 1). El gobierno afina el ajuste tributario. La Paz, Bolivia.

La Razón (2003b, February 4). La crisis se va a profundizar. La Paz, Bolivia.

La Razón (2003c, February 10). El rechazo a las medidas es unánime. La Paz, Bolivia.

La Razón (2003d, February 10). Goni anuncia el impuestazo. La Paz, Bolivia.

La Razón (2003e, February 11). Los salaries se achican. La Paz, Bolivia.

La Razón (2003f, February 11). Todos pagarán por igual 12.5\% de su salario. La Paz, Bolivia.

Levi, M. (1988). Of rule and revenue. Berkeley: University of California Press.

Lieberman, E. (2003). Race and regionalism in the politics of taxation in Brazil and South Africa. Cambridge: Cambridge University Press.

Lindblom, C. E. (1977). Politics and markets: The world's political economic systems. New York: Basic Books.

Luna, J. P. (2010). Segmented party voter linkages in Latin America: The case of the UDI. Journal of Latin American Studies, 42(2), $325-356$.

Mahon, J. (2004). Causes of tax reform in Latin America, 1977-95. Latin American Research Review, 99(1 February), 3-30.

Mahoney, J. (2010). After KKV: The new methodology of qualitative research. World Politics, 62(1), 120-147.

Mahoney, J., \& Thelen, K. (Eds.) (2010). Explaining institutional change. New York: Cambridge University Press.

Martin, I., \& Gabay, N. (2007). Do visible taxes cause protest? Tax policy and tax protest in rich democracies. Paper prepared for the meeting of the RC-19. Stockholm, September 4-6, 2008.

Miliband, R. (1969). The state and capitalist society. New York: Basic Books.

Mills, C. W. (1956). The power elite. Oxford: Oxford University Press.

Mkandawire, T. (2010). On tax efforts and colonial heritage in Africa. Journal of Development Studies, 46(10), 1647-1669.

Moore, M. (2004). Revenues, state formation and the quality of governance in developing countries. International Political Science Review, 25(3), 297-319.

Murillo, V. (2009). Political competition, partisanship, and policy making in Latin American public utilities. New York: Cambridge University Press.

Olson, M. (1965). The logic of collective action. Cambridge: Harvard University Press.

Perry, G. O. A., López, H., Maloney, W., \& Servén, L. (2006). Poverty reduction and growth. Washington, DC: World Bank.

Pierson, P. (1993). When effect becomes cause: Policy feedback and political change. World Politics, 45(4), 595-628.

Pierson, P. (1994). Dismantling the welfare state? Reagan, Thatcher, and the politics of retrenchment. New York: Cambridge University Press.
Piketty, T., Saez, E., \& Stantcheva, S. (2011). Optimal taxation of top labor incomes: A tale of three elasticities. Working paper No. 17616 Cambridge: National Bureau of Economic Research.

Prichard, W. (2009). The politics of taxation and implications for accountability in Ghana 1981-2008. Working paper 330. Institute for Development Studies, Sussex.

Przeworski, A., \& Wallerstein, M. (1988). Structural dependence of the state on capital. American Political Science Review, 82(1), 11-29 (March).

Roemer, J. (1999). Does democracy engender justice?. In I. Shapiro, \& C. Hacker- Cordón (Eds.), Democracy's value. New York: Cambridge University Press.

Saez, E. (2001). Using elasticities to derive optimal income tax rates. Review of Economic Studies, 68(January), 205-229.

Schamis, H. (1999). Distributional coalitions and the politics of economic reform in Latin America. World Politics, 51(January), 250.

Schneider, A. (2012). State-building and tax regimes in Central America. New York: Cambridge University Press.

Schneider, B. R. (2004). Organizing interests and coalition in the politics of market reform in Latin America. World Politics, 56(3), 456-479 (April).

Shleifer, A., \& Treisman, D. (2000). Without a map: Political tactics and economic reform in Russia. Cambridge: MIT Press.

Silva, E. (1996). The state and capital in Chile. Boulder: Westview Press.

Slater, D. (2010). Ordering power. Cambridge: Cambridge University Press.

Steinmo, S. (1993). Taxation and democracy: Swedish, British, and American approaches to financing the modern state. New Haven: Yale University Press.

Tilly, C. (1975). The formation of national states in Western Europe Princeton: Princeton University Press.

Timmons, J. (2005). The fiscal contract: States, taxes, and public services. World Politics, 57, 530-567.

Van Evera, S. (1997). Guide to methods for students of political science. Ithaca: Cornell University Press.

Weyland, K. (1997). Growth with equity in Chile's new democracy?. Latin American Research Review, 32(1), 37-67.

Weyland, K. (2002). The politics of market reform in fragile democracies: Argentina, Brazil, Peru, and Venezuela. Princeton: Princeton University Press.

Wilensky, H. (2002). Rich democracies: Political economy, public policy, and performance. Berkeley: University of Berkeley Press.

Wilson, J. Q. (1980). The politics of regulation. In J. Q. Wilson (Ed.), The politics of regulation. New York: Basic Books.

Winters, J. (1996). Power in motion. Ithaca: Cornell University Press.

\section{Author's interviews}

ABA (2006). Banking association informant. Buenos Aires. October 19. ADEBA (2006). Banking association informant. Buenos Aires. October 18 .

Baglini, R. (2006). UCR Senator. Buenos Aires, Argentina. September 13.

CChC (2005). Construction association staff member. Santiago, Chile. December 6.

CEPB (2006). President, Confederación de Empresarios Privados de Bolivia. La Paz, Bolivia. December 15.

CPC (2005). Former President, Confederación de Producción y Comercio. Santiago, Chile. December 13.

Economy Ministry-a (2006). Former Secretary of the Treasury (1996-99). Buenos Aires, Argentina. August 8.

Economy Ministry-b (2006). Former Subsecretary of Tax Policy (19961999). Buenos Aires, Argentina. September 4.

Economy Ministry-d (2006). Former Secretary of Public Revenue (19992001). Buenos Aires, Argentina. May 18.

Economy Ministry-c (2007). Former Argentine Economy Minister (19992001). Santiago, Chile. April 4

Finance Ministry-a (2007). Former Finance Minister (2000-05). Santiago, Chile. March 25.

Finance Ministry-b (2005). Santiago, Chile. October 13.

Finance Ministry-c (2005). Santiago, Chile. October 18.

Finance Ministry-d (2006). Former Vice Minister of Tax Policy. La Paz, Bolivia. December 13.

Finance Ministry-e (2007). Former Finance Minister (2002-03). La Paz, Bolivia. February 8. 
Finance Ministry-f (2007). Former Finance Minister (2004). La Paz, Bolivia. March 9.

Finance Ministry-g (2007). Former Vice-Minister of Tax Policy. La Paz, Bolivia. March 10.

Finance Ministry-h (2006). Vice-Ministry of Tax Policy informant. La Paz, Bolivia. December 13.

FDD (2012). Fundación Democracia y Desarrollo, Santiago, Chile. Telephone interview.

Lagos, R. (2006). Former Chilean President (2000-05). Berkeley, CA. September 20.

PDC (2007). Christian Democratic Senator. Santiago, Chile. March 26.

Private Sector-a (2005). Santiago, Chile. September 6.

Private Sector-b (2005). Santiago, Chile. November 30.

Prat, F. (2005). Former UDI senator. Santiago: Chile, Nov 28.

Sánchez de Lozada, G. (2010). Former Bolivian President (1993-97, 2002$03)$. Telephone interview. October 26.

SOFOFA (2005). Industry association staff member. Santiago, Chile. November 18.

Tax Agency (2005). Former tax agency director (1990-2002). Santiago, Chile. December 12

UDI (2005). UDI Deputy. Santiago, Chile. December 23.

\section{APPENDIX A. PROCESS-TRACING TESTS}

Methodologists have produced a wealth of literature on process tracing in recent years explicating the underlying logic of causal inference. This appendix reviews the central ideas in this literature and illustrates how process tracing forms the basis for my case analyses of the causal effect of reform strategies in Section 3, with specific reference to Chile's 2005 tax reform.

Process-tracing entails within-case analysis, which provides a distinct source of causal leverage from the cross-case, correlation-based inference employed in regression analysis. The pieces of evidence drawn from close analysis of a single case can be labeled "causal process observations" (CPOs) (Collier, Brady, \& Seawright, 2010; Mahoney, 2010). Researchers use CPOs to inductively build theory and to evaluate causal hypotheses. Drawing on Van Evera (1997), Bennett (2010) and Collier (2011) elaborate four evidence-based tests undergirding causal inference in process-tracing:

Straw-in-the-Wind Test: Passing the test increases the plausibility of the hypothesis in question but does not confirm it. Failing weakens the hypothesis, but does not eliminate it.

Hoop Test: Passing, or "jumping" through the hoop, increases the plausibility of the hypothesis but does not confirm it. If the hypothesis fails the test, it is eliminated.

Smoking-Gun Test: Passing confirms the hypothesis. Failing does not eliminate the hypothesis.

Doubly-Decisive Test: Passing confirms the hypothesis and eliminates rivals.

These tests can be classified by whether passing is necessary to establish causation (hoop; doubly-decisive), sufficient (smoking-gun; doubly-decisive), or neither (straw-in-the-wind) (Collier, 2011: 825). In practice, the terms necessary and sufficient are heuristics that need not be interpreted rigidly (Collier, 2011). Hence a smoking-gun test may be viewed as strongly affirming a hypothesis, as opposed to definitely confirming the hypothesis, or a particular test may be treated as having intermediate diagnostic power compared to the stronger and weaker types elaborated above. In essence, the four tests increase or decrease the likelihood that a hypothesis is correct to varying degrees, based on different logical criteria.

In light of these tests, CPOs may provide more or less decisive evidence in favor of or against a causal hypothesis (Ben- nett, 2010). Process tracing therefore resembles Bayesian analysis, where the researcher asks how surprising the evidence would be if a hypothesis were correct (Bennett, 2010). An inference therefore cannot be judged merely by the number of observations deployed. However, diverse sources and types of observations strengthen inference.

The following discussion explicitly illustrates how my analysis of Chile's 2005 reform draws on multiple CPOs and different types of tests. Where relevant, I discuss additional evidence not included in the article given space constraints. While I discuss the key diagnostic pieces of evidence, the causal inferences are grounded in a much larger body of comparative case knowledge acquired through extensive field research.

\section{A.1 Chile's stockholder tax subsidy reform}

Case summary: During the 2005 presidential campaign, right candidate Lavín blamed Chile's persistent inequality on the left and accused President Lagos of failing to deliver his promise of growth with equity. Lagos responded by publicly challenging the right to eliminate 57 bis, a highly regressive tax benefit for wealthy stockholders that he called "a tremendous support for inequality." The right accepted the challenge and voted in favor of eliminating the tax benefit in congress, deviating from its prior position on this policy and the preferences of its core business constituency.

The following three hypotheses encompass the main components of my argument regarding why the right voted in favor of the reform:

Hypothesis 1. Lagos' equity appeal motivated the right to accept the reform, due to concern over public opinion.

Hypothesis 2. The timing of the equity appeal—during a major electoral campaign — contributed to its success.

Hypothesis 3. The high issue-salience of inequality contributed to the equity appeal's success.

The following four observations, drawn from different sources, provide indirect, circumstantial support for Hypothesis 1 :

Observation 1a (p. 48): The Lagos administration considered eliminating 57 bis in the 2001 Anti-Evasion reform but judged it politically infeasible given business-right opposition (interview: Finance Ministry-a, 2005).

Observation 1b: The Lagos administration subsequently tried to reach an agreement with business to eliminate 57 bis without success (interview, Finance Ministry-b, 2005).

Observation 1c: Initiatives to eliminate the exemption were blocked in 1995 and 1998 due to right opposition. (Sources: congressional records, multiple interviews)

Observation 1d: Previous efforts to eliminate 57 bis did not involve concerted equity appeals. Although Concertación governments had mentioned equity in prior efforts, technical language predominated, and government statements focused much more on 57 bis' failure to stimulate investment rather than its regressive distributive impact (congressional records, La Segunda, March 27, 1998, El Mercurio, April 1, 1998, Interview, Ffrench-Davis, Santiago, Chile, Sept. 5, 2005).

Inference: These observations suggest that right votes to eliminate 57 bis would have been highly unlikely without some 
new, distinct political dynamic. Lagos' strong, high-profile equity appeal, in the unusual context of electoral competition from the right on the issue of inequality, becomes a strong candidate for explaining the right's acceptance of the reform.

Hypothesis 1 passes Straw-in-the-Wind Tests: The evidence is consistent with the hypothesis but is not decisive.

The following four observations provide more decisive evidence supporting Hypothesis 1 on the equity appeal's importance, and Hypothesis 2 on its timing:

Observation 2a (p. 49): Lavín's advisors attributed Lagos' narrow victory in the 1999 presidential election to the right's rejection of a labor-rights bill that the center-left government sent to congress during the campaign. The right compared the 1999 bill to the 2005 bill eliminating 57 bis. Lavín advisors commented: "The center-right is not willing to fall into the 1999 trap again." (El Mercurio, 2005e)

Observations 2b and c: Two additional articles from the same newspaper, which is widely recognized as having strong ties to the right and economic elites, referred to similar points regarding the right's comparison of the 1999 bill and the 2005 bill. (El Mercurio, 2005d; El Mercurio, 2005, June 15, 2005.)

Observation 2d (p. 49): A right-party senator explained: "the opposition demonstrated that this time it would accept things that usually it was not disposed to accept so as not to harm the presidential option - in this case it would do something popular." (Interview: UDI 2005)

Observation 2e: An informant from the right party UDI's think tank, who served as a technical advisor to the UDI's congressional bloc, explained: "the government said we have to eliminate 57 bis and I said that is a mistake, and they [the right legislators] said 'no, we will lose votes if we don't approve it."' (Interview, Instituto Libertad y Desarrollo, Santiago, Chile, Nov. 25, 2005.)

Inference: These five observations clearly indicate that the right was concerned that its presidential candidate would lose votes if right-party legislators defended 57 bis. Given the reasonable assumption that average citizens would not have been familiar with, or at least would not have been thinking about 57 bis - an obscure tax benefit for wealthy stockowners - prior to the exchange between Lavín and Lagos, we can attribute the right's manifest concern over public opinion to Lagos' equity appeal.

Hypothesis 1 passes Smoking-Gun Tests: Observations $2 \mathrm{a}-\mathrm{e}$ strongly support the hypothesis that the equity appeal motivated the right to accept the reform. This evidence would be extremely surprising if the null hypothesis that the equity appeal did not have an effect were correct.

Inference: These observations also establish the importance of timing for the equity appeal's success. Observations $2 \mathrm{a}-\mathrm{c}$ most clearly ground this inference, since the right drew lessons from a prior reform that was also proposed during a presidential campaign, as opposed to some other similar reform that was not proposed during a presidential campaign (e.g., the 2001 Anti-Evasion reform). Timing is also implicit in Observations $2 \mathrm{~d}$ and e, given express concern regarding the outcome of the presidential election, and the right legislator's reference to "this time" as distinct from other times.

Hypothesis 2 passes Smoking-Gun Tests: Observations $2 \mathrm{a}-\mathrm{c}$ provide decisive evidence that the electoral timing mattered. Observations $2 \mathrm{~d}$ and e also lend strong support to the hypoth- esis, but they give rise to weaker smoking-gun tests because they are not as decisive as observations $2 \mathrm{a}-\mathrm{c}$.

In this case, a few decisive observations strongly affirm Hypotheses 1 and 2. Observations 2a-e are particularly convincing because we would not expect sources from the right to acknowledge that a strategy implemented by the left affected the right's behavior.

Additional evidence from high-level government informants corroborates Hypothesis 1 and supports Hypothesis 3 regarding issue salience:

Observation 3a (p. 49): A Finance Ministry official observed that 57 bis "was a pure transfer of resources to rich people; there was no way to argue differently. ... It was not possible for the right to oppose the reform after making that argument about inequality." (interview: Finance Ministry-b, 2005).

Observation 3b: Former president Lagos maintained: " 57 bis never would have been eliminated if I had not taken Lavín at his word"-i.e., if Lagos had not taken seriously Lavín's publicly-professed concern over inequality. (interview, Lagos, 2006)

Inference: These observations suggest that the high-profile exchange on inequality between Lavín and Lagos, which culminated in Lagos' equity appeal, was critical for making the reform possible. Implicit in these quotations is the understanding that the high issue-salience of inequality - given the Bishops' denunciation of persistent inequality that motivated Lavín to blame lack of progress on Lagos (p. 48) as well as the subsequent exchange on inequality between Lavín and Lagos - mattered for reform. Since we know efforts to eliminate 57 bis failed on prior occasions, we can infer that the unusually high salience of inequality contributed to the equity appeal's success.

Hypotheses 1 and 3 pass (weaker) Smoking-Gun tests: These pieces of evidence strongly support the hypotheses, although they are less decisive for Hypothesis 1 than observations $2 \mathrm{a}-$ $\mathrm{e}$ - it is less surprising for the government to claim success for its strategy than for the right to acknowledge the strategy's impact.

In sum, core Hypothesis 1 passes straw-in-the-wind tests corresponding to four observations, smoking-gun tests corresponding to five observations, and weaker smoking-gun tests based on two additional observations. This evidence, particularly the smoking-gun observations, strongly affirms the hypothesis that equity appeals facilitated the reform.

Several CPOs listed above also rule out a plausible institutional explanation that challenges Hypothesis 1:

Hypothesis 4 (rival): The right would have accepted eliminating 57 bis regardless of the equity appeal, because Chile's institutionalized party system and stable rules of the game motivate cross-partisan cooperation in congress (drawing on Flores-Macías, 2010).

Observations 1a-c: The right opposed multiple prior attempts to eliminate 57 bis.

Inference: Since institutional incentives did not change significantly from the 1990s through the 2000s, if institutions created sufficient incentives for the right to accept the reform in 2005, they should have done so on prior occasions as well.

Hypothesis 4 fails Hoop Tests: The hypothesis is ruled out with respect to elimination of 57 bis. 
APPENDIX B.

\begin{tabular}{|c|c|c|c|c|c|}
\hline Strategy & $\begin{array}{c}\text { Primary } \\
\text { Mechanism }\end{array}$ & $\begin{array}{l}\text { Policy Choice / } \\
\text { Technique }\end{array}$ & $\begin{array}{l}\text { Limitations / } \\
\text { Drawbacks }\end{array}$ & Factors Affecting Success & Case Examples \\
\hline \multirow{4}{*}{$\begin{array}{c}\begin{array}{c}\text { Legitimating } \\
\text { Appeals }\end{array} \\
\text { 1. Vertical equity } \\
\text { 2. Horizontal equity }\end{array}$} & $\begin{array}{l}\text { 1. Mobilizes } \\
\text { public support }\end{array}$ & \multirow{4}{*}{$\begin{array}{l}\text { 1. Elite-targeted taxes } \\
\text { 2. Anti-evasion reforms; } \\
\text { Eliminating exemptions } \\
\text { (to a lesser extent) }\end{array}$} & \multirow[t]{4}{*}{ 1. May antagonize elites } & $\begin{array}{l}\text { Structure of voter-party linkages \& } \\
\text { political competition }\end{array}$ & $\begin{array}{l}\text { South Africa's income tax increases, } 1930-40 \mathrm{~s} \\
\text { (Lieberman 2003: 140): vertical equity }\end{array}$ \\
\hline & \multirow[t]{3}{*}{$\begin{array}{l}\text { 2. Tempers elite } \\
\text { antagonism }\end{array}$} & & & \multirow{3}{*}{$\begin{array}{l}\text { Enhanced by: } \\
\text { Strong political competition } \\
\text { Proximity to major elections } \\
\text { High issue salience }\end{array}$} & $\begin{array}{l}\text { Chile's } 2001 \text { Anti-evasion reform: } \\
\text { vertical \& horizontal equity }\end{array}$ \\
\hline & & & & & $\begin{array}{l}\text { Ghana's } 2001 \text { financial institution surcharge tax } \\
\text { (Prichard 2009: 18): vertical equity }\end{array}$ \\
\hline & & & & & $\begin{array}{l}\text { Obama's efforts to raise income taxes } \\
\text { on top U.S. earners: vertical equity }\end{array}$ \\
\hline \multirow[t]{2}{*}{$\begin{array}{l}\text { Attenuating } \\
\text { Impact }\end{array}$} & \multirow[t]{2}{*}{$\begin{array}{l}\text { Tempers elite } \\
\text { antagonism }\end{array}$} & \multirow[t]{2}{*}{$\begin{array}{l}\text { 1. Incremental reforms } \\
\text { 2. Phase-ins } \\
\text { 3. Temporary reforms }\end{array}$} & \multirow[t]{2}{*}{ Fiscal cost } & \multirow[t]{2}{*}{$\begin{array}{l}\text { Extent of attenuation required } \\
\text { increases with economic } \\
\text { elites' power }\end{array}$} & $\begin{array}{c}\text { Chile's } 1990 \text { corporate tax increase, } \\
\text { Colombia's 2000's wealth taxes (Flores 2012), } \\
\text { Guatemala's 2001, } 2004 \text { direct taxes (Schneider 2012): } \\
\text { temporary reforms }\end{array}$ \\
\hline & & & & & Chile's 2005 mining tax: phased-in \\
\hline $\begin{array}{l}\text { Obfuscating } \\
\text { Incidence }\end{array}$ & $\begin{array}{l}\text { Tempers elite } \\
\text { antagonism }\end{array}$ & $\begin{array}{l}\text { 1. Low-visibility taxes } \\
\text { 2. Burden-shifting }\end{array}$ & $\begin{array}{l}\text { Rarely feasible } \\
\text { 2. Uncertain incidence }\end{array}$ & $\begin{array}{l}\text { More effective for reforms } \\
\text { affecting non-elite taxpayers }\end{array}$ & Argentina's 1998 tax on corporate debt \\
\hline \multirow[t]{3}{*}{$\begin{array}{c}\text { Linking to } \\
\text { Popular Benefits }\end{array}$} & \multirow[t]{3}{*}{$\begin{array}{l}\text { Mobilizes public } \\
\text { support }\end{array}$} & $\begin{array}{l}\text { 1. Discursive } \\
\text { 2. Inclusion in }\end{array}$ & $\begin{array}{l}\text { May antagonize elites } \\
\text { 3. Requires exclusive }\end{array}$ & \multirow{3}{*}{$\begin{array}{l}\text { Same as for legitimating appeals, } \\
\text { but generally more effective } \\
\text { Clear, immediate, broad-based } \\
\text { benefits draw more support }\end{array}$} & \multirow{3}{*}{$\begin{array}{l}\text { Chile's } 1964 \text { tax increases } \\
\text { (Ascher 1984: 129) } \\
\text { Chile's } 1998 \text { anti-evasion reform: } \\
\text { contingent pension increases }\end{array}$} \\
\hline & & reform package & executive initiative & & \\
\hline & & $\begin{array}{l}\text { 3. Contingent benefits } \\
\text { 4. Earmarking }\end{array}$ & $\begin{array}{l}\text { 4. Budgetary rigidities, } \\
\text { Politically undesirable }\end{array}$ & & \\
\hline \multirow[t]{4}{*}{ Compensation } & \multirow[t]{4}{*}{$\begin{array}{l}\text { Tempers elite } \\
\text { antagonism }\end{array}$} & $\begin{array}{l}\text { 1. Separate negotiation } \\
2-4 \text { as above }\end{array}$ & $\begin{array}{c}\text { Potential fiscal cost } \\
3,4 \text {. as above }\end{array}$ & \multirow{4}{*}{$\begin{array}{l}\text { Magnitude of benefits required } \\
\text { increases with economic } \\
\text { elites' power } \\
\text { 1. Requires credible commitment } \\
\text { to deliver benefits }\end{array}$} & $\begin{array}{l}\text { Indonesia's } 1984 \text { reform } \\
\text { (Winters 1996: 169): inclusion in package }\end{array}$ \\
\hline & & & & & Argentina's 1998 corporate tax reform (Fairfield \\
\hline & & & & & $\begin{array}{l}\text { 2010): separately negotiated, sector-specific } \\
\text { compensations }\end{array}$ \\
\hline & & & & & $\begin{array}{l}\text { Colombia's 2000's wealth taxes (Flores 2012): } \\
\text { earmarked to internal security }\end{array}$ \\
\hline \multirow{2}{*}{$\begin{array}{l}\text { Emphasizing } \\
\text { Stabilization }\end{array}$} & \multirow{2}{*}{$\begin{array}{l}\text { Tempers elite } \\
\text { antagonism }\end{array}$} & \multirow{2}{*}{$\begin{array}{l}\text { Taxes that raise } \\
\text { revenue quickly }\end{array}$} & \multirow[t]{2}{*}{ Limited applicability } & \multirow{2}{*}{$\begin{array}{l}\text { Enhanced by: Imminent crisis, } \\
\text { History of hyperinflation or crises }\end{array}$} & Bolivia's 2004 financial transactions tax \\
\hline & & & & & $\begin{array}{c}\text { Ghana's } 2001 \text { financial institution surcharge tax } \\
\text { (Prichard 2009: 18) }\end{array}$ \\
\hline
\end{tabular}

See above-mentioned references for further information.

${ }^{1}$ Corporate tax incentives eliminated in exchange for lower overall tax rates and a simplified tax system.

Available online at www.sciencedirect.com 